\title{
CALIBRATION AND VALIDATION OF REFERENCE EVAPOTRANSPIRATION MODELS IN SEMI-ARID CONDITIONS
}

\author{
ISLAM, S. ${ }^{{ }^{*}}-$ ABDULlAH, R. A. B. ${ }^{1}-$ BADRUDDIN, I. A. $^{2}-{\text { AlgAHTANI, A. }{ }^{2,3}-\text { SHAHID, }}{ }^{1}{ }^{1}-$ \\ IRSHAD, K. ${ }^{4}-$ MALLICK, J. ${ }^{5}-$ HIROL, H. ${ }^{1}-$ AlSUBIH, M. ${ }^{5}$ - ElOUNI, M. H. ${ }^{5,6}$ - KAHLA, N. B. ${ }^{5,6}$ \\ ${ }^{1}$ Department of Civil Engineering, University Teknologi Malaysia, P.O. Box 81310 Johor \\ Bahru, Johor, Malaysia \\ ${ }^{2}$ Department of Mechanical Engineering, College of Engineering, King Khalid University, \\ Abha 61413 Asir, Kingdom of Saudi Arabia \\ ${ }^{3}$ Research Centre for Advanced Materials Science (RCAMS), King Khalid University, P.O. Box \\ 9004, Abha-61413, Asir, Kingdom of Saudi Arabia \\ ${ }^{4}$ Center of Research Excellence in Renewable Energy (CoRERE), King Fahd University of \\ Petroleum \& Minerals, Dhahran, Saudi Arabia \\ ${ }^{5}$ Department of Civil Engineering, College of Engineering, King Khalid University, Abha \\ 61413, Asir, Kingdom of Saudi Arabia \\ ${ }^{6}$ Laboratory of Systems and Applied Mechanics, Tunisia Polytechnic School, University of \\ Carthage La Marsa, Tunis 2078, Tunisia. \\ *Corresponding author \\ e-mail: isaiful2@graduate.utm.my; phone: +966-59-521-9933; fax: +966-17-241-8816 \\ (Received $13^{\text {th }}$ Sep 2019; accepted $4^{\text {th }}$ Dec 2019)
}

\begin{abstract}
Reference evapotranspiration (ETo) is an important parameter for climatological, hydrological and agricultural management. The FAO56 Penman-Monteith (FAO56-PM) model is one of the most accurate models. But it needs a detailed climate dataset from weather stations. Therefore, empirical reference evapotranspiration models (ETo) that need a reduced set of climate data can become an alternative approach. In this study, nine different evapotranspiration models were calibrated for the 19782000 period and validated based on the period between 2001-2017 with respect to standard FAO56-PM method based on the real climatic data obtained from Aseer metrological department, Saudi Arabia. The ranking of all the evaluated models based on the multi-criteria decision making was done in order to get the best alternative to the FAO56-PM Model. The result showed that Mahringer and Trabert models are the most appropriate with RMSE values of $2.13 \mathrm{~mm} /$ day and $2.47 \mathrm{~mm} /$ day, respectively and the value of percent error were $77.27 \%$ and $89.43 \%$, respectively. Moreover, the values of mean bias error were found to be $-2.03 \mathrm{~mm} /$ day and $-2.35 \mathrm{~mm} /$ day, respectively. The calibration and validation of different ETo equations tend to increase their performance. Thus, the validated evapotranspiration model that used less climatic parameters could predict the ETo condition accurately for any region.
\end{abstract}

Keywords: water management, agricultural management, climate, ranking, entropy, AHP

\section{Introduction}

Having an accurate estimation of crop water requirements is crucial for good planning so that water resources can be utilized efficiently (Jin et al., 2018). The most important factors for water resource planning and irrigation scheduling is the determination of reference evapotranspiration ETo (Jiang et al., 2017; Tie et al., 2018). Therefore, precise estimation of ETo is essential for net irrigation water requirement, regional water management, 
environmental studies and climate change impacts (Wei et al., 2016; Gabri et al., 2019). The method of estimating the evapotranspiration is using a lysimeter. It can provide high accuracy while measuring the evapotranspiration (Hausler et al., 2018). However, these methods are very costly and require much expensive and sophisticated equipment for measurement. As a result, the FAO56-PM Model which bears the high correlation with lysimeter measurement is used for the estimation of evapotranspiration (Allen et al., 1998). Although FAO56-PM method is rigorously used in different part of the world, it still requires various climatic parameters as an input to compute the reference evapotranspiration. Hence, based on the limited climatic parameters, researchers have developed and estimated numerous ETo equations around the world (Djaman et al., 2015, 2016a). Therefore, empirical methods, including mass transfer, radiation, temperature and pan evaporation-based methods have been developed to estimate the reference crop evapotranspiration using the limited data. Although different ETo methods can provide the estimated ETo with relatively good accuracy, they fail to adapt to all the climatic conditions. As a result, the performance of these ETo equations needs to improve under various weather conditions ( $\mathrm{Li}$ et al., 2018). During the past few years, many studies have been conducted to evaluate various evapotranspiration model but very few studies are focusing on the calibration and validation of evapotranspiration model (Table 1) with respect to the standard FAO56-PM model. Considerable effort has been exerted to evaluate other methods using FAO56-PM as the standard ( $\mathrm{Hu}$ et al., 2009). Trajkovic and Kolakovic (2009) evaluated five evapotranspiration equations under the humid conditions and concluded that the Turc equation is suitable to estimate the reference evapotranspiration at humid locations, especially when the weather data are limited. Calibration and validation of six evapotranspiration model were performed in the Senegal river delta and it can be concluded that the preciseness of the result can be enhanced substantially as the error was decreased after calibration (Djaman et al., 2016a). Besides that, eleven equations to calculate the monthly ETo were calibrated (Zhai et al., 2010). After calibration, the differences of the regional suitability disappeared or even reversed. In addition, the ETo equations with lysimeter results and found radiation-based method can perform much better as compared to the temperature-based model after calibration (Xu et al., 2013). Pandey and Pandey (2018) performed the calibration and ranking of seven Valiantzas reference evapotranspiration equations for the study period of 2006-2016 under the humid climate at North India. The result showed that Valiantaz model 7 has the best performance. However, the study is lacking the validation of calibrated equation. Djaman et al. (2017a) performed the validation of Valiantzas' reference evapotranspiration equation under humid, sub-humid and semiarid conditions in Africa. The analysis showed that the Valiantzas' ETo equation could become an alternative to the FAO56-PM equation without calibration to follow the local humid, sub-humid and semiarid climatic conditions. However, the analysis is lacking evaluation of different ETo equations. Djaman et al. (2016b) performed the evaluation of the FAO56-PM model with limited data and the Valiantzas models for estimating evapotranspiration in agro-ecological zones of Burkina Faso, West Africa. The result showed that Valiantzas 2 equation with full climatic data has resulted in good ETo estimates relative to the FAO56-PM. However, the calibration and validation are not incorporated in the study. Djaman et al. (2016a) performed the calibration and validation of six ETo model in Senegal river basin, West Africa and concluded that the Valiantzas 2 equation was the best model for the Senegal river delta. However, the ranking operation is not performed in the equation. Albelewi et al. (2015) assessed six evapotranspiration models in the hyper-arid environment in Saudi Arabia. The study concluded that FAO56-PM is the most accurate ETo model to estimate crop water irrigation needs in hyper-arid environments. 
However, the validation of the model is not incorporated in the study. Djaman et al. (2015) evaluated sixteen reference evapotranspiration methods under the sahelian conditions in the Senegal river valley. The study showed that Valiantaz is the most promising model that can be used as an alternative to the FAO56-PM model. However, the ranking of the equation is lacking in this study. Pandey et al. (2016) evaluated eighteen reference evapotranspiration methods for the northeastern region of India. The findings revealed that Irmak3 and Turc models performed equally well and are the best among the selected models for the majority of stations. However, the validation of the calibrated equation is not performed in the study. Cadro et al. (2017) performed the validation and calibration of eleven reference evapotranspiration alternative methods under the climate conditions of Bosnia and Herzegovina and concluded that Trajkovic method is the best model. Djaman et al. (2017b) evaluated eleven reference evapotranspiration models in semiarid conditions and concluded that the Abtew equation showed the best performance among the selected ETo equations but the validation and ranking are lacking in the analysis. Bogawski and Bednorz (2014) made comparison and validation of selected evapotranspiration models for conditions in Poland (Central Europe). This approach could substantially decrease the errors produced by the recommended non-calibrated equations. However, there is no ranking procedure involved in the analysis. Lang et al. (2017) make a comparative study of evapotranspiration estimation by eight methods with FAO56-PM method in Southwestern China. The result showed that the radiation-based methods performed better than temperature-based methods among the selected methods in the study area. Among the radiation-based methods, Makking performed the best while Hargreaves and Samani showed the best performance among the temperaturebased methods. However, the calibration and ranking are lacking in the study.

The past studies were basically assessed different ETo models against the FAO56-PM model based on the Central and Eastern region and few in southern region of Saudi Arabia (Salih and Sendil, 1984; Saeed, 1986; Mustafa et al., 1989; Al-Omran and Shalaby, 1992; Abo-Ghobar and Mohammad, 1995; Elnesr et al., 2010; Islam et al., 2019a,b). However, in high mountain environments, such as the Abha Asir region, Saudi Arabia, meteorological monitoring is limited and high-quality data are scarce. Moreover, measurements of relative humidity by electronic sensors are commonly plagued by hysteresis, nonlinearity and calibration errors (Allen, 1996). There is no significant work related to the calibration and validation of different evapotranspiration model with respect to standard FAO56-PM in Abha city of Asia region. Based on an extensive literature review, it can be concluded that there are no comprehensive studies being conducted to evaluate the performance of empirical models in the semi-arid region, Abha Aseer, Kingdom of Saudi Arabia on the basis of calibration validation and ranking, especially on a monthly timescale. To fill in this research gap, in this study, an effort was made to estimate the evapotranspiration from a different model based on the availability of meteorological data for the period 1978-2017 and ranking has been done using multi-criteria decision making method. This can aid in recognizing the suitable method that can be used as an alternative equation to standard FAO56-PM method. The finding of the research work is helpful in reducing the error during the evapotranspiration computation. Moreover, the best-evaluated model equation the for evapotranspiration could assist in computing the evapotranspiration in future in the field of water management system, climate change studies, irrigation and water resource planning. 
Table 1. Summarization of the previous studies

\begin{tabular}{|c|c|c|c|c|}
\hline Sno & Methods/Region & Performance indicator & Remarks & Reference \\
\hline 1 & $\begin{array}{l}\text { Valiantaz Equation (1 to 7) } \\
\text { (Humid-subtropical, } \\
\text { Northern India) }\end{array}$ & $\begin{array}{c}\mathrm{R}^{2} \text { (Coefficient of } \\
\text { determination), D (Index of } \\
\text { agreement), MAE (Mean } \\
\text { absolute error), MBE (Mean bias } \\
\text { error), Weighted root mean } \\
\text { square error (WRMSE) }\end{array}$ & $\begin{array}{l}\text { Valiantaz } 2 \text { can be Recommended } \\
\text { for daily ETo estimation under } \\
\text { conditions of missing data in } \\
\text { northeast India. With } \mathrm{R}^{2}(0.95), \mathrm{D} \\
(0.988), \text { MAE }(0.151), \mathrm{MBE} \\
(-0.026), \text { WRMSE }(0.206)\end{array}$ & $\begin{array}{l}\text { (Pandey and } \\
\text { Pandey, } \\
\text { 2018) }\end{array}$ \\
\hline 2 & $\begin{array}{c}12 \text { alternative ETo model } \\
\text { (Bosnia and Herzegovina } \\
\text { region) }\end{array}$ & $\begin{array}{l}\text { Mean bias error (MBE), } \\
\text { Root mean square difference } \\
\text { (RMSD), Mean Absolute error } \\
\text { (MAE), Coefficient of } \\
\text { determination }\left(\mathrm{R}^{2}\right)\end{array}$ & $\begin{array}{c}\text { Trajkovic method best model } \\
\text { RMSD (from } 0.157 \text { to } \\
0.243 \mathrm{~mm} / \text { day), MAE }(0.121 \text { to } \\
0.173 \mathrm{~mm} / \text { day), MBE }(0.266 \text { to } \\
0.080) \mathrm{R}^{2}(0.952 \text { to } 0.980)\end{array}$ & $\begin{array}{l}\text { (Cadro et al., } \\
\text { 2017) }\end{array}$ \\
\hline 3 & $\begin{array}{l}\text { Valiantzas equation using } 61 \\
\text { weather stations across } 10 \\
\text { African countries (humid, } \\
\text { sub-humid and semiarid } \\
\text { conditions in Africa) }\end{array}$ & $\begin{array}{l}\text { Root mean squared error } \\
\text { (RMSE), Percent error (PE), } \\
\text { Mean bias error (MBE), and } \\
\text { Mean absolute error (MAE) }\end{array}$ & $\begin{array}{l}\text { The Valiantzas' ETo equation } \\
\text { could be an alternative to the } \\
\text { Penman-Monteith equation } \\
\text { without calibration, RMSE values } \\
\text { that varied from } 0.03 \text { to } \\
0.27 \mathrm{~mm} / \text { day, percent error PE } \\
\text { from } 0.87 \text { to } 5.46 \%, \text { MBE from } \\
-0.09 \text { to } 0.23 \mathrm{~mm} / \text { day and MAE } \\
\text { from } 0.03 \text { to } 0.23 \mathrm{~mm} / \text { day }\end{array}$ & $\begin{array}{l}\text { (Djaman et } \\
\text { al., 2017a) }\end{array}$ \\
\hline 4 & $\begin{array}{c}\text { Jensen and Haise, Hansen } \\
\text { method, Abtew Christiansen, } \\
\text { Droogers and Allen, } \\
\text { Hargreaves and Allen Irmak } \\
\text { method, Tabari } 1 \text { and } 2 \\
\text { (Semi Arid region, Mali } \\
\text { West Africa) }\end{array}$ & $\begin{array}{c}\text { Root mean squared error } \\
\text { (RMSE), relative error (RE), } \\
\text { mean bias error } \\
\text { (MBE), and the absolute mean } \\
\text { error (AME) }\end{array}$ & $\begin{array}{c}\text { The Abtew ETo equation is best } \\
\text { one, RMSE varying from } 0.20 \text { to } \\
0.58 \mathrm{~mm} / \text { day and average RE, } \\
\mathrm{MBE} \text { and MAE of } 6.7 \% \text {, } \\
-0.25 \mathrm{~mm} / \text { day and } 0.30 \mathrm{~mm} / \text { day. }\end{array}$ & $\begin{array}{l}\text { (Djaman et } \\
\text { al., 2017b) }\end{array}$ \\
\hline 5 & $\begin{array}{l}\text { Makkink (Mak), Abtew } \\
\text { (Abt), and Priestley-Taylor } \\
\text { (PT), Hargreaves-Samani } \\
\text { (HS), Thornthwaite (Tho), } \\
\text { Hamon (Ham), Linacre (Lin), } \\
\text { and Blaney-Criddle (BC) } \\
\text { (Southwestern China) }\end{array}$ & $\begin{array}{l}\text { Nash-Sutcliffe efficiency, } \\
\text { (NSE), relative error (Re), } \\
\text { normalized root mean squared } \\
\text { error (NRMSE) and linear } \\
\text { regression }\end{array}$ & $\begin{array}{c}\text { NSE }(0.34-0.86), \operatorname{Re}(-0.10 \text { to } \\
-0.13), \text { NRMSE }(0.12-0.14), \mathrm{R} 2 \\
(0.96-0.98) \\
\text { Radiation-based Makkink } \\
\text { methods shows better } \\
\text { performance }\end{array}$ & $\begin{array}{l}\text { (Lang et al., } \\
\text { 2017) }\end{array}$ \\
\hline 6 & $\begin{array}{c}\text { Trabert, Mahringer, } \\
\text { Penman1948, Albrecht, } \\
\text { Valiantzas1 and Valiantzas2 } \\
\text { (Senegal River Basin, West } \\
\text { Africa) }\end{array}$ & $\begin{array}{c}\text { Root mean squared error } \\
\text { (RMSE), Mean bias error } \\
\text { (MBE), Percentage Error (PE) }\end{array}$ & $\begin{array}{l}\text { Valiantzas } 2 \text { equation was the } \\
\text { best-performing model for the } \\
\text { Senegal River-Delta and had the } \\
\text { lowest root mean squared } \\
\text { difference (RMSE) of } \\
0.45 \mathrm{~mm} / \text { day, MBE of - } \\
0.05 \mathrm{~mm} / \text { day and the lowest } \\
\text { percent error of estimate (PE) } \\
\text { about } 7.1 \% \text {. }\end{array}$ & $\begin{array}{l}\text { (Djaman et } \\
\text { al., 2016a) }\end{array}$ \\
\hline 7 & $\begin{array}{l}\text { Valiantaz } 1 \text { and } 2 \text { equation } \\
\text { (Agro-ecological zones of } \\
\text { Burkina Faso, West Africa) }\end{array}$ & $\begin{array}{c}\text { Root mean squared error } \\
\text { (RMSE), Mean bias error (MBE) }\end{array}$ & $\begin{array}{l}\text { ETo-Val } 1 \text { method, RMSE varied } \\
\text { from } 0.43 \text { to } 0.57 \mathrm{~mm} / \text { day and the } \\
\text { MBE varied from }-0.05 \text { to } \\
0.04 \mathrm{~mm} / \text { day whereas the ETo- } \\
\text { Val- } 2 \text { method had the RMSE } \\
\text { ranging from } 0.59 \text { to } 2.11 \mathrm{~mm} / \text { day } \\
\text { and the MBE ranging from } 0.26 \\
\text { to } 1.90 \mathrm{~mm} / \text { day. (The Valiantzas } \\
2 \text { equation with full climatic data } \\
\text { resulted in good ETo estimates) }\end{array}$ & $\begin{array}{l}\text { (Djaman et } \\
\text { al., 2016b) }\end{array}$ \\
\hline 8 & $\begin{array}{l}12 \text { Radiation based, } 6 \\
\text { temperature based (Humid } \\
\text { Region,North India) }\end{array}$ & $\begin{array}{l}\text { Index of agreement (d), Mean } \\
\text { absolute error (MAE),Standard } \\
\text { Error of estimates (SEE), } \\
\text { Weighted root mean square } \\
\text { difference RMSD (WRMSD) }\end{array}$ & $\begin{array}{l}\text { Radiation-based equations of } \\
\text { IRMAK3, TURC, } 1957 \text { MAKK, } \\
\text { and MODTURC had superior and } \\
\text { consistent performance d(0.88- } \\
0.96), \text { MAE }(0.15-0.28 \mathrm{~mm} / \text { day }), \\
\text { SEE }(0.13-0.38 \mathrm{~mm} / \text { day }), \\
\text { WRMSD }(0.23-0.35 \mathrm{~mm} / \text { day })\end{array}$ & $\begin{array}{l}\text { (Pandey et } \\
\text { al., 2016) }\end{array}$ \\
\hline 9 & $\begin{array}{c}\text { FAO-56 Penman-Monteith, } \\
\text { Priestly Taylor, Hargreaves- } \\
\text { Samani, Makkink (MK), } \\
\text { Turc (hyper-arid } \\
\text { condition,Saudi Arabia) }\end{array}$ & $\begin{array}{l}\text { Coefficient of determination } \\
\left(\mathrm{R}^{2}\right), \text { Coefficient of efficiency } \\
(\mathrm{E}), \text { Modified coefficient of } \\
\text { efficiency (E1), Root mean } \\
\text { square error (RMSE), } \\
\text { Coefficient of residual mass } \\
\text { (CRM) }\end{array}$ & $\begin{array}{l}\mathrm{R}^{2}(0.64-0.97), \mathrm{E}(0.73-0.95), \mathrm{E} 1 \\
(0.47-0.78), \mathrm{RMSE}(0.33-0.77), \\
\text { CRM (-0.02-0.13) FAO-56 PM is } \\
\text { the most accurate, ETo model. }\end{array}$ & $\begin{array}{l}\text { (Alblewi et } \\
\text { al., 2015) }\end{array}$ \\
\hline
\end{tabular}




\begin{tabular}{|c|c|c|c|c|}
\hline Sno & Methods/Region & Performance indicator & Remarks & Reference \\
\hline 10 & $\begin{array}{c}\text { Hargreaves and Samani, } \\
\text { Trajkovic, Ravazzani et al, } \\
\text { Modified Hargreaves, } \\
\text { Schendel, Trabert, Penman } \\
\text { (1948,1963), Romanenko, } \\
\text { Romanenko's modified } \\
\text { equation, Mahringer, Turc, } \\
\text { Makkink, Makkink modified, } \\
\text { Valiantzas } 1 \text { method, } \\
\text { Valiantzas } 2 \text { method } \\
\text { (Senegal River Valley) }\end{array}$ & $\begin{array}{c}\text { Root mean squared error } \\
\text { (RMSE), Mean absolute error } \\
\text { (MAE), Percentage error (PE) } \\
\text { and Mean ratio (MR) }\end{array}$ & $\begin{array}{l}\text { Valiantaz } 2 \text { most promising model } \\
\text { with RMSE }(0.79 \mathrm{~mm} / \text { day }), \text { MAE } \\
(0.63 \mathrm{~mm} / \text { day }) \mathrm{PE}(2.47 \%), \mathrm{MR}(1)\end{array}$ & $\begin{array}{c}\text { (Djaman et } \\
\text { al., 2015) }\end{array}$ \\
\hline
\end{tabular}

\section{Material and Methods}

\section{Site Description}

The research work deals with Abha mountainous region of Aseer province, Kingdom of Saudi Arabia having an area of $370 \mathrm{~km}^{2}$ located between the latitude of $18^{\circ} 10^{\prime} 12.39^{\prime \prime} \mathrm{N}$ and $18^{\circ} 23^{\prime} 33.05^{\prime \prime} \mathrm{N}$ and longitude of $42^{\circ} 21^{\prime} 41.58^{\prime \prime} \mathrm{E}$ and $42^{\circ} 39^{\prime} 36.09^{\prime \prime} \mathrm{E}$ as shown in Fig. 1.

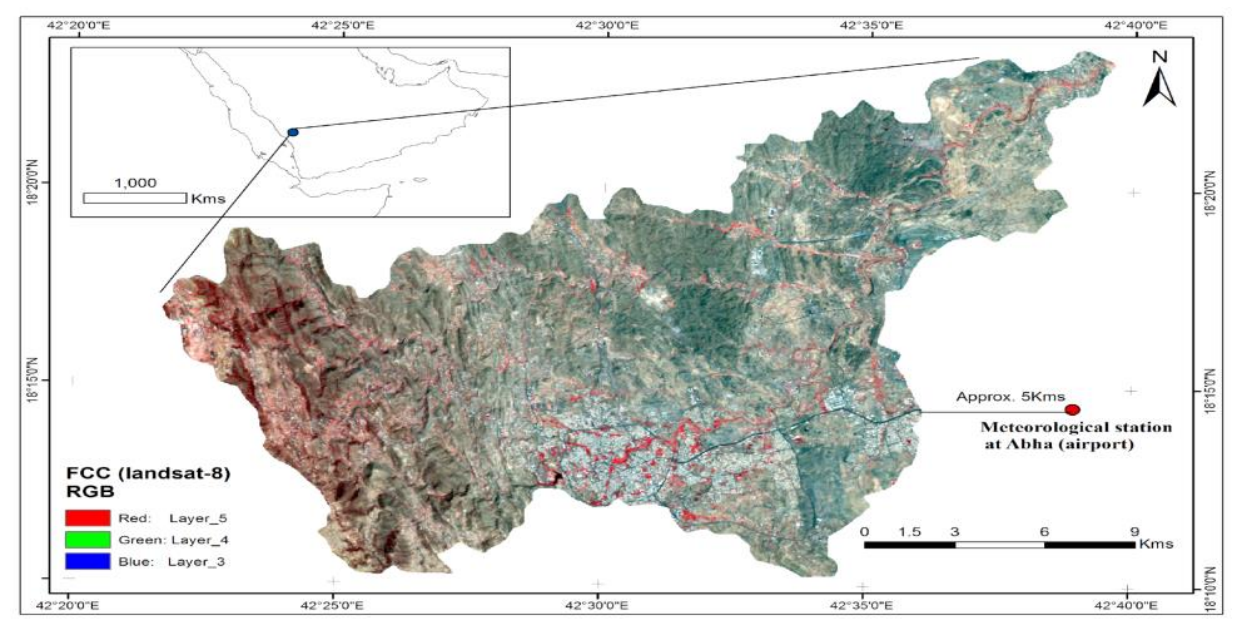

Figure 1. Location map of Abha Asir region, Kingdom of Saudi Arabia

The zone is prone to heavy rainfall as compared to other parts of Saudi Arabia. The elevation varies from 1951 to $2991 \mathrm{~m}$ (msl) with average precipitation of $355 \mathrm{~mm}$ which mainly occurs between June and October. According to the topographical features of the investigation region, it is found to have weak geology because of the precipitation and slope nature during the past few years. It was observed that this area is facing problem-related to the soil disintegration which influences the efficiency of agriculture, especially water characteristics of catchment zones.

\section{Data Availibility}

In this research work, primary (raw) weather parameters were collected from Abha meteorological weather station for the period between 1978-2017 (40 years) which includes wind velocity, maximum and minimum temperature, mean temperature, mean relative humidity and solar radiation as well. The data collected were checked by Allen (1996). The weather data are shown in Table 2. 
Table 2. Characteristics of Abha weather parameters during the study period

\begin{tabular}{c|c|c|c|c|c|c|c}
\hline & $\mathbf{U 2}(\mathbf{m} / \mathbf{s})$ & $\mathbf{T} \max \left({ }^{\circ} \mathbf{C}\right)$ & $\operatorname{Tmin}\left({ }^{\circ} \mathbf{C}\right)$ & $\operatorname{Tmean}\left({ }^{\circ} \mathbf{C}\right)$ & $\begin{array}{c}\mathbf{R H} \\
\text { mean\% }\end{array}$ & $\begin{array}{c}\mathbf{S R} \\
\left(\mathbf{M J m}^{-2} \mathbf{d}^{-1}\right)\end{array}$ & $\begin{array}{c}\text { Vapour Pressure } \\
\text { Deficit }(\mathbf{k P a})\end{array}$ \\
\hline Min & 0.75 & 20.3 & -0.4 & 11.9 & 14 & 16.8 & 0.2 \\
Max & 5.23 & 35.1 & 21.4 & 25.1 & 88 & 25.5 & 2.9 \\
Mean & 2.36 & 28.5 & 9.2 & 18.7 & 54.7 & 21.9 & 1.2 \\
ST-Dev & 0.64 & 3.7 & 4.4 & 3.73 & 12.9 & 2.5 & 0.5 \\
\hline
\end{tabular}

\section{Methodology}

Various ETo estimation techniques taking into account distinctive data prerequisites are available in the literature. In this research work ETo were estimated by nine reference evapotranspiration model based on available climatic data. Among nine model four model were mass transfer based i.e., Trabert (1896), Mahringer (1970), Penman (1948), Albrecht (1950). Four model were radiation based i.e., Priestley and Taylor (1972), Turc (1961), Makkink modified (1967), Makkink (1957) and one combination based Valiantzas (2013) model. Moreover, the reference ETo values were estimated using standardized FAO56-PM. The values estimated from different equations were compared with the reference value obtained from FAO56-PM for the period between 1978-2017. Further all nine equations were calibrated for the period between 1978-2000 then validation of calibrated equation for the period between 2001-2017 with respect to FAO56-PM model. The performance of equations was evaluated by utilizing several statistical measures such as root mean square value, mean bias error, standard error of estimates, percentage error respectively and finally based on evaluation criteria the ranking was done in order to get most promising model which can be used alternative to FAO56-PM model. The flowchart as shown in Fig. 2 described the stepwise procedure to compute most promising model among nine model to be used as alternate of FAO56-PM model.

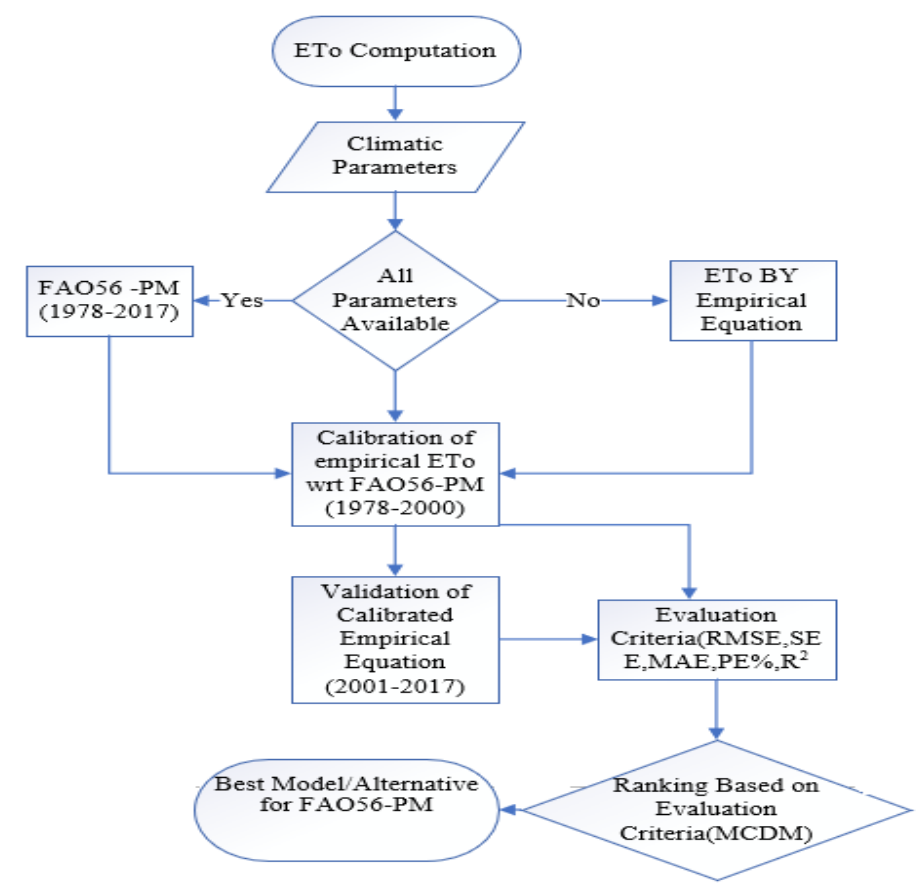

Figure 2. Flowchart showing stepwise computation of ETo 


\section{Reference Evapotranspiration (ETo) Model}

This study work aims to analyze trends of the monthly ETo calculated by the Standard FAO56-PM model (Eq. l) in the Abha Asir region, Kingdom of Saudi Arabia. However, the use of the FAO56-PM is limited by the insufficiency of climatic input parameters, and the alternative is to employ simple empirical models. The following mass transfer combination and temperature based alternative methods (Eq. 2-11) for estimating ETo have been chosen for this study. The selection of methods was based on their wide acceptance, simple calculation procedure and applicability in present conditions.

FAO Penman -Monteith (Allen et al., 1998)

$$
\text { ETo }=\frac{0.408 \times \Delta \times(R n-G)+\gamma \times\left(\frac{900}{T+273}\right) \times u_{2} \times\left(e_{s}-e_{a}\right)}{\Delta+\gamma \times\left(1+0.34 u_{2}\right)}
$$

Trabert (1896)

$$
\text { ETo }=0.408 \times 0.3075 \times \sqrt{u_{2}} \times\left(e_{s}-e_{a}\right)
$$

Mahringer (1970)

$$
E T o=0.15072 \times \sqrt{3.6 u_{2}} \times\left(e_{s}-e_{a}\right)
$$

Penman (1948)

$$
E T o=0.35 \times\left(1+0.24 u_{2}\right) \times\left(e_{s}-e_{a}\right)
$$

Albrecht (1950)

$$
\text { ETo }=\left(0.1005+0.297 u_{2}\right) \times\left(e_{s}-e_{a}\right)
$$

Priestley and Taylor (1972)

$$
\text { ETo }=1.26 \times\left(\frac{\Delta}{\Delta+y}\right) \times\left(\frac{R_{n}-G}{\lambda}\right)
$$

Turc (1961)

$$
\begin{gathered}
E T o=0.013 \times\left(\frac{T}{T+15}\right) \times\left(R_{s}+50\right) \times\left(1-\frac{50-R H}{70}\right) R H<50 \\
E T_{0}=0.013 \times\left(\frac{T}{T+15}\right) \times\left(R_{s}+50\right) \quad R H<50
\end{gathered}
$$

Makkink (1967) modified Hansen (1984)

$$
E T o=0.7 \times\left(\frac{\Delta}{\Delta+\gamma}\right) \times\left(\frac{R_{s}}{\lambda}\right)
$$


Makkink (1957)

$$
E T o=0.61 \times\left(\frac{\Delta}{\Delta+\gamma}\right) \times\left(\frac{R_{s}}{\lambda}\right)-0.12
$$

Valiantaz (2013)

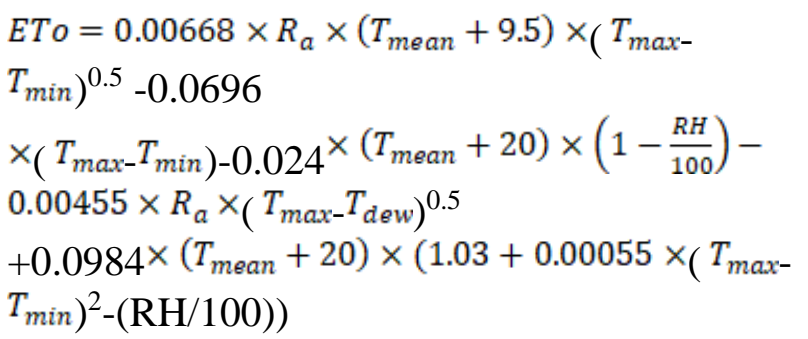

where $\mathrm{ETo}=$ reference evapotranspiration $\left(\mathrm{mm} \mathrm{day}^{-1}\right) ; \mathrm{Rn}=$ net radiation at the crop surface $\left(\mathrm{MJm}^{-2}\right.$ day $\left.^{-1}\right) ; \mathrm{G}=$ soil heat flux density $\left(\mathrm{MJm}^{-2}\right.$ day $\left.^{-1}\right)$ ) that is taken as zero for daily ETo estimation; $\mathrm{u}_{2}=$ wind speed at $2 \mathrm{~m}$ height $\left(\mathrm{m} \mathrm{s}^{-1}\right) ; \mathrm{e}_{\mathrm{s}}=$ saturation vapor pressure $(\mathrm{kPa}) ; \mathrm{e}_{\mathrm{a}}=$ actual vapor pressure $(\mathrm{kPa}) ; \mathrm{T}=$ temperature at $2 \mathrm{~m}$ height $\left({ }^{\circ} \mathrm{C}\right)$; $\left(\mathrm{e}_{\mathrm{s}}-\mathrm{e}_{\mathrm{a}}\right)=$ vapor pressure deficit $(\mathrm{kPa}) ; \Delta=$ slope of vapor pressure curve $\left(\mathrm{kPa}^{\circ} \mathrm{C}^{-1}\right)$; and $\gamma=$ psychrometric constant $\left(\mathrm{kPa}{ }^{\circ} \mathrm{C}^{-1}\right) ; \mathrm{T}_{\max }=$ Maximum Temperature $\left({ }^{\circ} \mathrm{C}\right)$; $\mathrm{T}_{\text {min }}=$ Minimum Temperature $\left({ }^{\circ} \mathrm{C}\right) ; \mathrm{T}_{\text {mean }}=$ Mean Temperature $\left({ }^{\circ} \mathrm{C}\right) ; \mathrm{RH}_{\text {mean }}=$ Mean Relative Humidity (\%); $\mathrm{RH}_{\max }=$ Maximum Relative Humidity $(\%) ; \mathrm{RH}_{\min }=$ Minimum Relative Humidity (\%).

\section{Model Validation}

For the validation of FAO56-PM ETo model, the estimated result of FAO56-PM were compared with value measured from Davis Vantage Pro2 weather stations installed in Abha region. The instrument provides real-time data for weather conditions. It uses air temperature, relative humidity, average wind speed, and solar radiation data to estimate ETo, which is calculated once an hour. Validation of FAO56-PM with measured value as represented by Fig. 3. After evaluating FAO56-PM with measure ETo the RMSE and MBE value found to be 0.144 and $0.011 \mathrm{~mm}$ while coefficient of determination found to be 0.987 with slope and intercept of 1.013 and -0.032 , respectively.

\section{Calibration and Validation of ET $T_{O}$ Equations}

The linear regression model was employed to calibrate and validate the empirical models against the FAO56-PM model (Allen et al., 1998). The specific expression is as shown in Eq. 12.

$$
E T_{F A 056-P M}=a \cdot E T_{E M P}+b
$$

where $\mathrm{ET}_{\mathrm{FAO} 6 \text {-PM }}$ and $\mathrm{ET}_{\mathrm{EMP}}$ represent the daily reference evapotranspiration estimated by the FAO56-PM model and the nine empirical models respectively whereby and a and $\mathrm{b}$ are calibrated empirical coefficients. In this research work, the climatic data from 1978-2000 were used for the development of the calibrated equations and data from 
2000-2017 were applied for validation purpose. This partitioning is important as more data is required for the models' training.

The main objective of calibrating ETo was to make the slope equally inclined to both $\mathrm{x}$ and $\mathrm{y}$ axis and intercept reaching zero. For this purpose, a linear regression was done in between Standard PM-ETo and values were obtained through the nine ETo equations. To accomplish this, calibration coefficients need to be determined which can be obtained by applying product operation to the slope of a regression line between the FAO56-PM-ETo and ETo equation by inversing the slope. This will get a new slope so that the new equation will be closer to unity. Moreover, opposite sign value of the intercept was added to get a new intercept close to zero for new regression equation. The calibration and validation of ETo estimates were performed as suggested by (Xu et al., 2013).

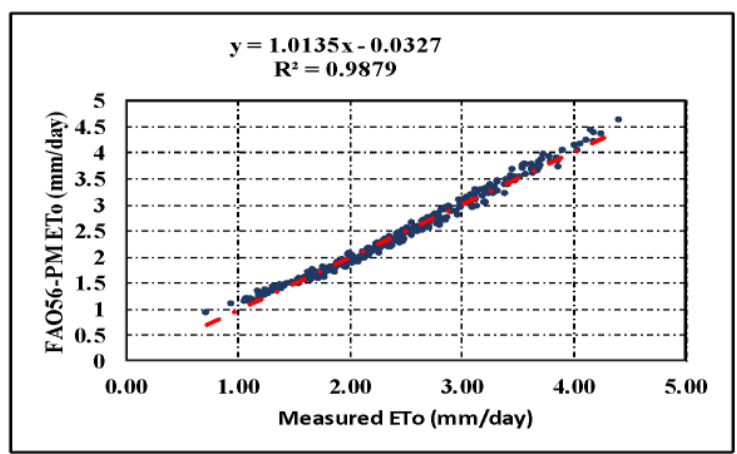

Figure 3. Validation of Standard FAO56-PM ETo with Measured ETo

\section{Comparison of the Performance of Different ETo Methods}

The comparative study was performed for the FAO56-PM model and the rest of the local nine ETo equations by making use of the scatter plot. The linear regression line was plotted to get the the coefficient of determination. The high value of coefficient shows the best sign of goodness of fit for the observations (Djaman et al., 2016a). Moreover, the performance indicator such as root mean squared error (RMSE) (Eq. 13), mean bias error (MBE) (Eq. 14), percent error of estimate (PE) (Eq. 15), the standard error of estimate (SEE) (Eq. 16), Correlation Coefficient $\left(\mathrm{R}^{2}\right)(E q$. 17) were used to compare the nine ETo models. A comprehensive statistical analysis was used to analyze the model results against the observed data. Moreover, it can also be employed to test the agronomical models. The significance of root mean square error is that it is an absolute measure of the overall error in the estimates relative to the observed values which are expressed in the same units and scale as the data itself. It can take any positive value with zero indicating a perfect lack of error.

Root Mean Square Error

$$
\mathrm{RMSE}=\sqrt{\sum_{\mathrm{i}=1}^{\mathrm{n}} \frac{\left(\mathrm{ET}_{\mathrm{Eq}}-\mathrm{ET}_{\mathrm{PM}-\mathrm{FAO}}\right)^{2}}{\mathrm{n}}}
$$

Similarly, the mean bias error (MBE) measures the extent to which the estimated value deviates from the observed value. It can take any value with negative values 
indicating the systematic under-estimation and positive values, over-estimation and zero indicating a perfect lack of bias.

Mean Bias Error

$$
\begin{gathered}
\mathrm{MBE}=\sum_{\mathrm{i}=1}^{\mathrm{n}} \frac{\left(\mathrm{ET}_{\mathrm{Eq}}-\mathrm{ET}_{\mathrm{PM}-\mathrm{FAO}}\right)}{\mathrm{n}} \\
\mathrm{PE}=\left|\frac{\left(\mathrm{ET}_{\mathrm{Eqav}}-\mathrm{ET}_{\mathrm{PM}-\mathrm{FAOav}}\right)}{\mathrm{ET}_{\mathrm{PM} \text {-FAOav }}}\right| \times 100
\end{gathered}
$$

The SEE was computed following the equation as shown below:

$$
\begin{aligned}
& \text { SEE } \\
& =\sqrt{\left(\frac{1}{\mathrm{n}(\mathrm{n}-2)}\left[\mathrm{n} \sum_{\mathrm{i}=1}^{\mathrm{n}} \mathrm{ET}_{\mathrm{eq}}{ }^{2}-\left(\sum_{\mathrm{i}=1}^{\mathrm{n}} \mathrm{ET}_{\mathrm{eq}}\right)^{2}-\frac{\left[\mathrm{n} \sum_{\mathrm{i}=1}^{\mathrm{n}} \mathrm{ET}_{\mathrm{FA056}-\mathrm{PM} \times} \mathrm{ET}_{\mathrm{eq}}-\sum_{\mathrm{i}=1}^{\mathrm{n}} \mathrm{ET}_{\mathrm{FA056}-\mathrm{PM}} \times \sum_{\mathrm{i}=1}^{\mathrm{n}} \mathrm{ET}_{\mathrm{eq}}\right]^{2}}{\mathrm{n} \sum_{\mathrm{i}=1}^{\mathrm{n}} \mathrm{ET}^{2}{ }_{\mathrm{FA} 056-\mathrm{PM}}-\left(\sum_{\mathrm{i}=1}^{\mathrm{n}} \mathrm{ET}_{\mathrm{FA056}-\mathrm{PM}}\right)^{2}}\right]\right.}
\end{aligned}
$$

Correlation Coefficient

$$
R^{2}=1-\frac{\sum_{i=1}^{n}\left(E T_{O, M i}-E T_{o, F A O 56-P M}\right)^{2}}{\sum_{i=1}^{n}\left(E T_{O, M i}-E T_{O, M i_{a v}}\right)^{2}}
$$

where, $E T_{O, M i} E T_{O, M i}=$ Reference evapotranspiration by ith model; $E T_{O, F A 056-P M}=$ Reference evapotranspiration by Standard model 1; SD = Standard Deviation.

\section{Ranking}

Many researchers employ multi-criteria decision making (MCDM) methods to cope with water-related problems in their studies (Makropoulos et al., 2008) such as river basin planning (Qin et al., 2008), water supply reservoir (e.g. Srdjevic et al., 2004), urban water management (Zarghami et al., 2008), groundwater management (Pietersen, 2006), wetland management (Janssen et al., 2005), and irrigation planning (Gupta et al., 2000). Senent-Aparicio et al. (2017) uses SWAT and Fuzzy TOPSIS to assess the Impactof Climate Change in Segura River Basin (SE Spain). The present study deals MCDM technique (Entropy for weightage and TOPSIS for performance) for ranking ETo models (alternatives) using statistical indices (criterias), coefficient of determination, standard error of estimate, mean bias error, root mean square error and percent error. The value of SEE, RMSE, MBE and PE is indirectly proportional to the rank called as non-beneficial criteria. Moreover, $\mathrm{R}^{2}$ value is directly proportional to the rank called as beneficial criteria. The performance value (greater the value better will be the model) of different ETo models will decide the promising model in Abha region which is one of the novelty in this research work.

\section{Entropy Method}

\section{Objective Weight}

The objective weight is determined by Entropy method by making use of probability theory (Vinogradova et al., 2018).

The decision matrix A with $\mathrm{m}$ alternatives and $\mathrm{n}$ criteria is shown by Eq. 18 . 


$$
A=\left[\begin{array}{ccc}
x_{11} & \cdots & x_{1 n} \\
\vdots & \ddots & \vdots \\
x_{m 1} & \cdots & x_{m n}
\end{array}\right]
$$

where $x_{i j}(i=1,2, \ldots, m ; j=1,2, \ldots, n)$ shows the performance value of the $i^{\text {th }}$ alternative to the $\mathrm{j}^{\text {th }}$ criteria.

The normalized decision matrix is calculated using Eq. 19.

$$
P_{i j}=\frac{x_{i j}}{\sqrt{\sum_{i=1}^{m} x_{i j}^{2}}}
$$

The entropy $\mathrm{E}_{\mathrm{j}}$ of the jth criteria is computed by Eq. 20 .

$$
E_{j}=-k \sum_{i=1}^{m} P_{i j} \ln \left(P_{i j}\right) j=1,2, \ldots, n
$$

A constant that ensures $0 \leq E_{j} \leq 10 \leq E_{j} \leq 1$ in the $k=1 / \ln m k=1 / \ln m$ where $m$ presents the number of choices.

The degree of divergence $\left(\mathrm{d}_{\mathrm{j}}\right)$ computed by Eq. 21 .

$$
\mathrm{d}_{\mathrm{j}}=\left|1-\mathrm{E}_{\mathrm{j}}\right|
$$

The jth criteria entropy weight is computed by Eq. 22 .

$$
\beta_{j}=\frac{d_{j}}{\sum_{j=1}^{n} d_{j}}
$$

\section{Topsis Method}

The TOPSIS method (Alamanos et al., 2018) is expressed in a succession of six steps as follows:

Step 1: The normalized value of matrix as in Equation 18 is calculated by Eq. 23 .

$$
\overline{X_{l j}}=\frac{X_{i j}}{\sqrt{\sum_{j=1}^{n} X_{i j}^{2}}}
$$

where $i=1,2, \ldots, m$ and $j=1,2, \ldots, n$.

Step 2: The weighted normalized value is computed by multiplying the normalized value by weightage of criterios obtained by Eq. 22 .

Step 3: Determine the ideal best value $\left(\mathrm{V}_{\mathrm{J}}^{+}\right)$and ideal negative value $\left(\mathrm{V}_{\mathrm{J}}^{-}\right)$from weightage normalized value.

Step 4: The Euclidean distance of each alternative from the ideal best solution ( $E q$. $24)$ and the ideal worst solution (Eq. 25), respectively, are as follows:

$$
S_{i}^{+}=\left[\sum_{j=1}^{m}\left(V_{i j}-V_{j}^{+}\right)^{2}\right]^{0.5}
$$




$$
S_{i}^{-}=\left[\sum_{j=1}^{m}\left(V_{i j}-V_{j}^{-}\right)^{2}\right]^{0.5}
$$

Step 5: The performance score is computed by Eq. 26.

$$
P_{i}=\frac{S_{i}^{-}}{S_{i}^{+}+S_{i}^{-}}
$$

Step 6: Rank the alternatives (greater the $\mathrm{P}_{\mathrm{i}}$ value better will be rank).

\section{Results}

\section{Evaluation of Reference Evapotranspiration Equations for the 1978-2017 Period}

The comparative study of all reference evapotranspiration equation with Standard Penman-Monteith equation is shown in Fig. 4a-i. The plot clearly stated that the Evapotranspiration value from all the nine equations has a high correlation with the PM-ETo with the coefficient of determination $\mathrm{R}^{2}$ range from 0.54 to 0.96 . The highest correlation was shown by Albrecht model while the lowest correlation was Makkink method. The best fit of a model is measured by the linear regression line slope close to unity and the intercept to zero. The variation of slope and intercept of the Trabert model were found to be 0.114 and -0.053 , respectively and the value of the coefficient of determination was 0.944 (Fig. 4a). Similarly, slope and intercept of the Mahringer model (Fig. 4b) were found to be 0.261 and -0.12 , respectively and the value of the coefficient of determination was 0.944 . Moreover, slope and intercept of the Penman model (Fig. 4c) were found to be 0.421 and -0.81 , respectively and the value of the coefficient of determination was 0.941. Meanwhile, slope and intercept of the Albrecht model (Fig. 4d) were found to be 0.473 and -0.225 and the value of the coefficient of determination was 0.963 . The slope and intercept of the Priestly Taylor model (Fig. 4e) were found to be 1.126 and 1.039, respectively and the value of the coefficient of determination was 0.733 . From Fig. $4 f$, it can be seen that the slope and intercept of the Turc model were found to be 0.287 and 0.981 , respectively and the value of the coefficient of determination was 0.659. In Fig. $4 g$, the slope and intercept of the Makkink Modified Hansen model were found to be 0.63 and 2.958, respectively and the value of the coefficient of determination was 0.54 . The slope and intercept of the Makkink (1957) model (Fig. 4h) were found to be 0.549 and 2.459, respectively and the value of the coefficient of determination was 0.54. Similarly, the slope and intercept of the Valiantaz model (Fig. 4i) were found to be 0.457 and 0.511 and the value of the coefficient of determination was 0.673 . The slope that was closer to one was observed in Priestly Taylor method. On the other hand, the intercept that was closer to zero was shown by Trabert model. The regression equation for evaluation, calibration and validation are shown in Table 3) The accuracy of the result was performed using evaluation criteria like RMSE, SEE, MBE and PE values as shown in Table 4. Statistical analysis showed that all the selected equations underestimated ETo. The RMSE values were ranging from 0.98 to $2.36 \mathrm{~mm}$ /day with the minimum error shown by Valiantaz model and maximum error shown by Trabert model. The MBE values were ranging from 0.78 to $2.24 \mathrm{~mm}$ /day with the minimum error shown by Turc model. 
The SEE values were ranging from 0.023 to 0.571 with the minimum error shown by Trabert and the maximum error shown by the Priestly Taylor method. The PE\% were ranging from 90.70 to 33.53 with minimum error shown by the Valiantaz model.
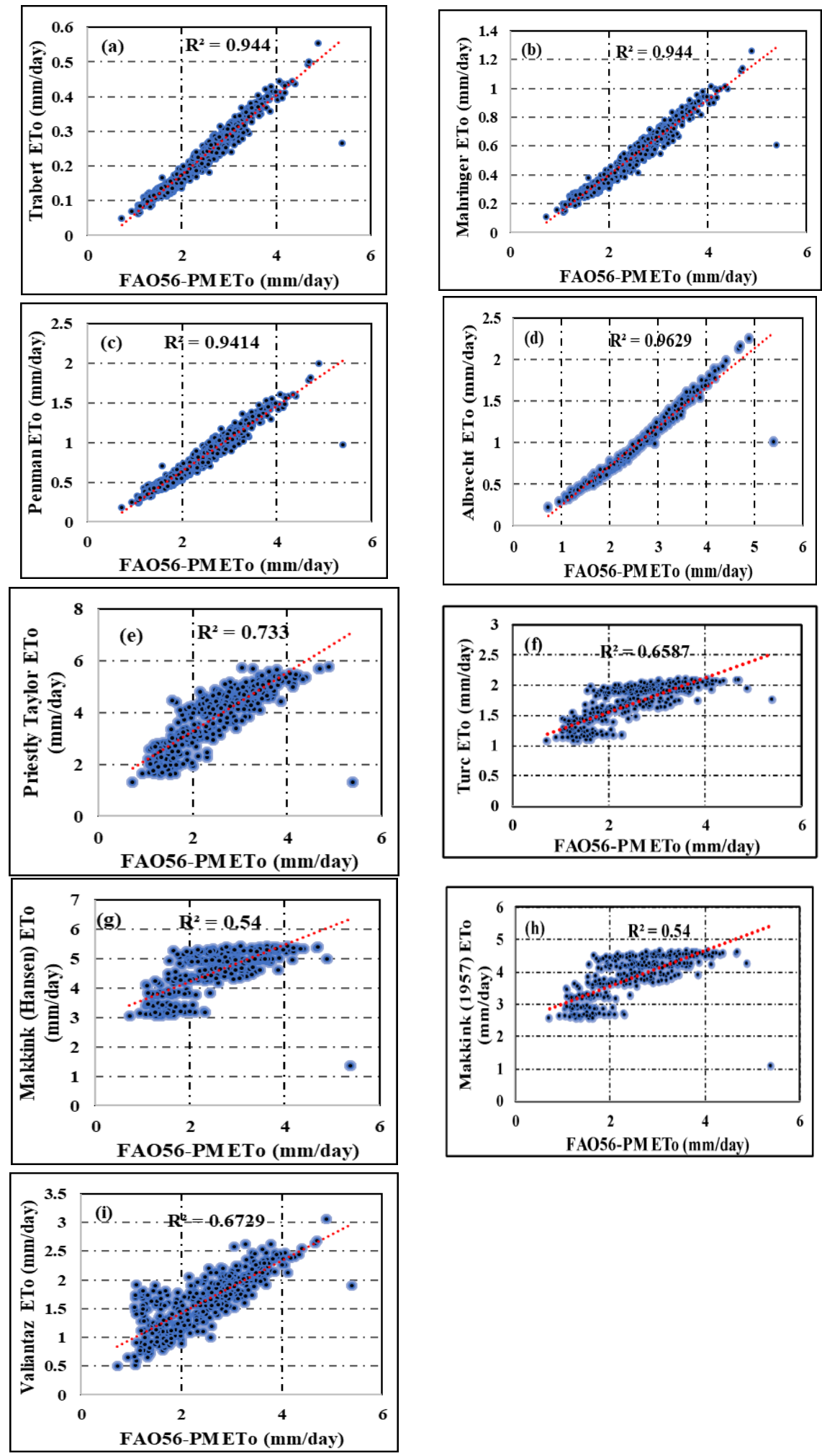

Figure 4. Relationship between the daily ETo estimates of each method versus the FAO56-PM at Abha for the 1978-2017 period 
Table 3. Regression equation for Evaluation, Calibration and validation

\begin{tabular}{c|c|c|c|c}
\hline SN & Method & Evaluation & Calibration & Validation \\
\hline 1 & Trabert & $\mathrm{y}=0.114 \mathrm{x}-0.0528$ & $\mathrm{y}=1.0149 \mathrm{x}-0.0326$ & $\mathrm{y}=0.1108 \mathrm{x}-0.0136$ \\
2 & Mahringer & $\mathrm{y}=0.2607 \mathrm{x}-0.1203$ & $\mathrm{y}=1.0105 \mathrm{x}-0.0355$ & $\mathrm{y}=0.2539 \mathrm{x}-0.0699$ \\
3 & Penman & $\mathrm{y}=0.412 \mathrm{x}-0.1813$ & $\mathrm{y}=1.0114 \mathrm{x}-0.0332$ & $\mathrm{y}=0.4012 \mathrm{x}-0.127$ \\
4 & Albrecht & $\mathrm{y}=0.473 \mathrm{x}-0.225$ & $\mathrm{y}=1.0132 \mathrm{x}-0.0314$ & $\mathrm{y}=0.4599 \mathrm{x}-0.0 .1726$ \\
5 & Priestly-Taylor & $\mathrm{y}=1.1258 \mathrm{x}+1.0394$ & $\mathrm{y}=1.0588 \mathrm{x}-0.0894$ & $\mathrm{y}=1.0189 \mathrm{x}+1.1118$ \\
6 & Turc & $\mathrm{y}=0.2869 \mathrm{x}+0.9811$ & $\mathrm{y}=1.0587 \mathrm{x}-0.0803$ & $\mathrm{y}=0.2609 \mathrm{x}+1.0072$ \\
7 & Makkink (Hansen) & $\mathrm{y}=0.63 \mathrm{x}+2.9573$ & $\mathrm{y}=1.0963 \mathrm{x}-0.1422$ & $\mathrm{y}=0.5373 \mathrm{x}+2.8613$ \\
8 & Makkink(1957) & $\mathrm{y}=0.549 \mathrm{x}+2.4574$ & $\mathrm{y}=1.0963 \mathrm{x}-0.1409$ & $\mathrm{y}=0.4681 \mathrm{x}+2.4252$ \\
9 & Valiantaz & $\mathrm{y}=0.4575 \mathrm{x}+0.5107$ & $\mathrm{y}=1.048 \mathrm{x}+0.1694$ & $\mathrm{y}=0.4012 \mathrm{x}+0.7759$ \\
\hline
\end{tabular}

Table 4. Evaluation of criteria parameters for ET estimate between 1978-2017

\begin{tabular}{c|c|c|c|c|c}
\hline & $\mathbf{R}^{\mathbf{2}}$ & SEE & RMSE & MBE & PE \\
\hline Trabert-ET0(mm) & 0.94 & 0.023 & 2.36 & 2.24 & 90.70 \\
Mahringer-ET0(mm) & 0.94 & 0.053 & 2.04 & 1.94 & 78.81 \\
Penman-ET0(mm) & 0.94 & 0.086 & 1.71 & 1.63 & 66.15 \\
Albrecht-ET0(mm) & 0.96 & 0.078 & 1.59 & 1.52 & 61.82 \\
Priestly Taylor-ET0(mm) & 0.73 & 0.571 & 1.47 & 1.35 & 54.75 \\
Turc -ET0(mm) & 0.66 & 0.174 & 1.00 & 0.78 & 31.50 \\
Makkink-Modified Hansen ET0(mm) & 0.54 & 0.489 & 2.13 & 2.05 & 83.00 \\
Makkink 1957 ET0(mm) & 0.54 & 0.426 & 1.46 & 2.17 & 54.60 \\
Valiantaz ET0 (mm) & 0.67 & 0.268 & 0.98 & 0.83 & 33.53 \\
\hline
\end{tabular}

\section{Calibration of the Reference Evapotranspiration Equations between 1978-2000}

The main objective of the model calibration is to improve the performance of all equations. The computed result from the year 1978 to 2000 was used to calibrate the evapotranspiration equation. Based on the calibration procedure as shown in Fig. $5 a-i$, it can be observed that the coefficient for determination improved substantially with values of $\mathrm{R}^{2}$ ranges from 0.61 to 0.99 whereby high correlation was shown by Albrecht model and lower value by Makkink method. The slope and intercept of the Trabert model were found to be 1.015 and -0.033 , respectively and the value of the coefficient of determination was 0.963 (Fig. 5a). Similarly, the slope and intercept of the Mahringer model (Fig. 5b) were found to be 1.01 and -0.036 , respectively and the value of the coefficient of determination was 0.963. In Fig. 5c, the slope and intercept of the Penman model were found to be 1.011 and -0.033 , respectively and the value of the coefficient of determination was 0.961 . The slope and intercept of the Albrecht model (Fig. 5d) were found to be 1.013 and -0.031 , respectively and the value of the coefficient of determination was 0.985 . In Fig. 5e the slope and intercept of the Priestly Taylor model were found to be 1.059 and -0.089 , respectively and the value of the coefficient of determination was 0.77. Similarly, in Fig. 5f, the slope and intercept of the Turc model were found to be 1.059 and -0.08 , respectively and the value of the coefficient of determination was 0.66. The slope and intercept of the Makkink Modified Hansen model (Fig. 5g) were found to be 1.096 and -0.142 , respectively and the value of the coefficient of determination was 0.609. In Fig. 5h the slope and intercept of the Makkink (1957) model were found to be 1.096 and -0.169 , respectively and the value of the coefficient of determination was 0.609. Similarly, in Fig. 5i the slope and intercept 
of the Valiantaz were found to be 1.048 and -0.169 , respectively and the value of the coefficient of determination was 0.681 . The slope that was closer to one was observed in Mahringer model while the intercept that was closer to zero was shown by Albrecht model.
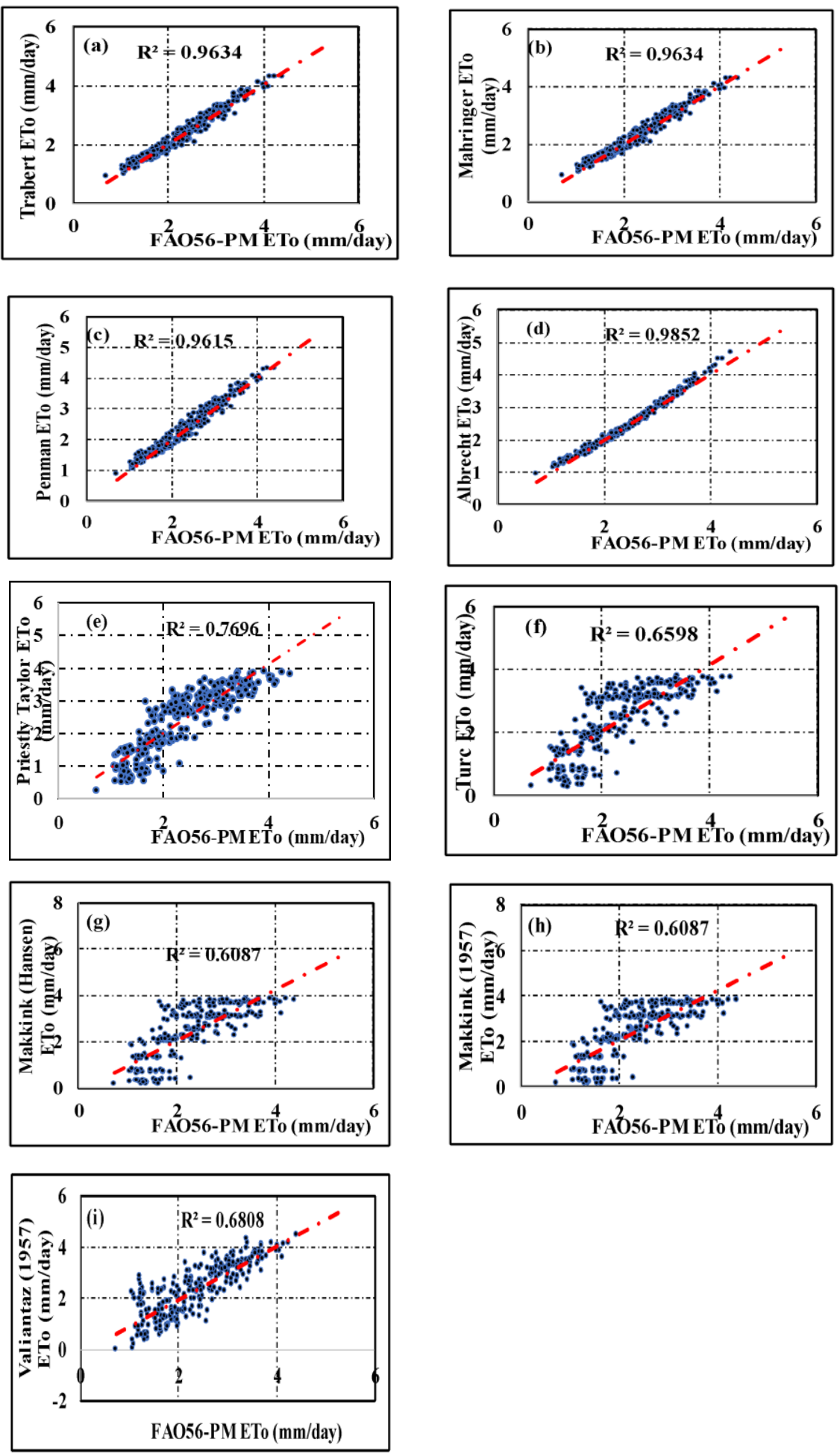

Figure 5. Relationship between the calibrated daily ETo estimates of each method versus the FAO56-PM at Abha for the 1978-2000 period 
The RMSE values were ranging from 0.1 to $0.71 \mathrm{~mm} /$ day with the minimum error shown by Albrecht model and maximum error is shown by Makkink model. The MBE values were ranging from -0.14 to $0.09 \mathrm{~mm}$ /day with the minimum error shown by Albreht and Trabert. The SEE values were ranging from 0.1 to 0.7 with the minimum error shown by Albrecht and Maximum error shown by Makkink method. The PE\% were ranging from 3.63 to 0.01 with minimum error shown by Albrecht model. There was considerable a reduction in RMSE and MBE values for all the equations after calibration as shown in Table 5. The percentage error also reduced significantly whereby the maximum reduction in error percentage was found to be in Trabert Model in which the error reduced from 90.70 to $0.1 \%$. However, there was no improvement in SEE values as the error increased slightly in Priestly Taylor method whereby the error reduced from 0.57 to 0.46 .

Table 5. Evaluation of criteria parameters for calibrated ET estimate between 1978-2000

\begin{tabular}{c|c|c|c|c|c}
\hline & $\mathbf{R}^{2}$ & SEE & RMSE & MBE & PE \\
\hline Trabert-ET0(mm) & 0.96 & 0.16 & 0.16 & 0.00 & 0.10 \\
Mahringer-ET0(mm) & 0.96 & 0.16 & 0.16 & -0.01 & 0.47 \\
Penman-ET0(mm) & 0.96 & 0.16 & 0.16 & -0.01 & 0.28 \\
Albrecht-ET0(mm) & 0.99 & 0.10 & 0.10 & 0.00 & 0.01 \\
Priestly Taylor-ET0(mm) & 0.77 & 0.46 & 0.46 & 0.05 & 2.07 \\
Turc -ET0(mm) & 0.66 & 0.60 & 0.61 & 0.00 & 2.44 \\
Makkink-Modified Hansen ET0(mm) & 0.61 & 0.70 & 0.71 & 0.09 & 3.57 \\
Makkink 1957 ET0(mm) & 0.61 & 0.70 & 0.71 & 0.09 & 3.63 \\
Valiantaz ET0(mm) & 0.68 & 0.57 & 0.57 & -0.14 & 2.42 \\
\hline
\end{tabular}

\section{Validation of ET Model from Calibrated Equation for Period between 2001-2017}

Nine calibrated evapotranspiration equations have been validated for the period of 2001-2017 in order to show which calibrated equation perform well and can be further employed as an alternative to Standard FAO Penman Monteith model.

From the validation procedure as shown in Fig. $6 a-i$, it can be observed that the coefficient of determination improved substantially with values of $\mathrm{R}^{2}$ ranges from 0.48 to 0.936 with high correlation shown by Albrecht model and lower value by Makkink method. The slope and intercept of the Trabert model were found to be 0.111 and 0.014 , respectively and the value of the coefficient of determination was 0.919 (Fig. 6a). Similarly, the slope and intercept of the Mahringer model (Fig. 6 b) were found to be 0.254 and -0.07 , respectively and the value of the coefficient of determination was 0.919. In Fig. $6 c$ the slope and intercept of the Penman model were found to be 0.401 and -0.127 , respectively and the value of the coefficient of determination was 0.916 . The slope and intercept of the Albrecht model (Fig. 6d) were found to be 0.46 and 0.173 , respectively and the value of the coefficient of determination was 0.936. In Fig. $6 e$ the slope and intercept of the Priestly Taylor model were found to be 1.019 and 1.112, respectively and the value of the coefficient of determination was 0.696. In Fig. ff the slope and intercept of the Turc model were found to be 0.261 and 1.007, respectively and the value of the coefficient of determination was 0.667. Similarly, in Fig. $6 g$ the slope and intercept of the Makkink Modified Hansen model were found to be 0.537 and 2.86, respectively and the value of the coefficient of determination was 0.48. The slope and intercept of the Makkink (1957) model (Fig. 6h) were found to be 0.468 and 2.425 , respectively and the value of the coefficient of determination was 0.48 . In Fig. $6 i$ the slope and intercept of the Valiantaz model were found to be 0.4 and 0.776 , 
respectively and the value of the coefficient of determination was 0.647 . The slope that was closer to one was observed in the Priestly Taylor model while the intercept closer to zero was shown by Trabert model.
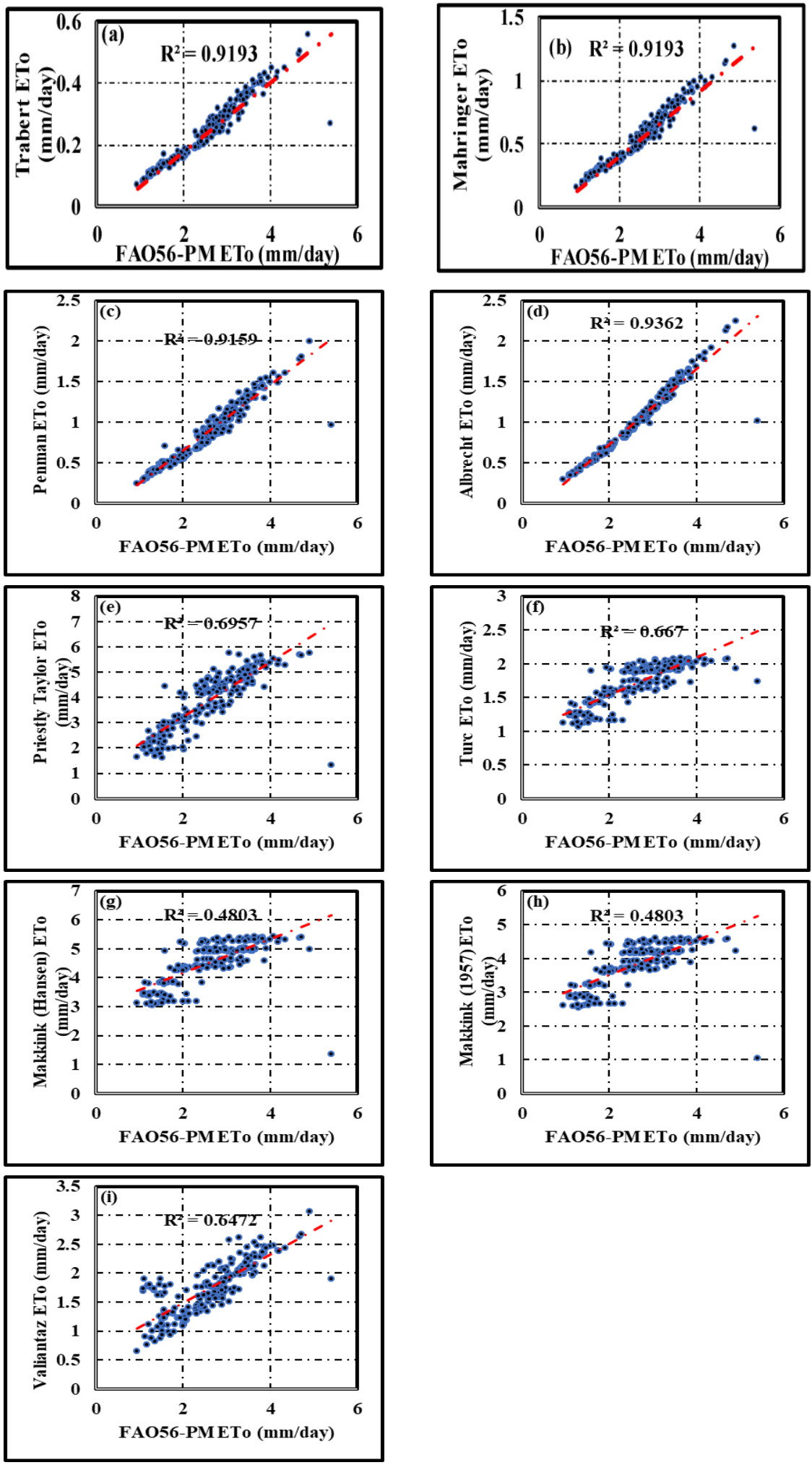

Figure 6. Validating the calibrated equation for the period between 2001-2017 
The statistical analysis as shown in Table 6 illustrates that there is a close relationship between the validated equation result with the Penman Monteith estimates. Similar to the output of the calibrated equation, the result obtained from SEE, RMSE, $\mathrm{MB}$ and PE showed a similar pattern with only slightly decrease in $\mathrm{R}^{2}$. The value of SEE, RMSE, MBE and PE is acceptable for ETo estimation with any of the nine ETo equations at Abha station. However, Validated Valiantzas equation $\left(\mathrm{R}^{2}=0.65\right.$, the lowest RMSE $0.99 \mathrm{~mm} /$ day and the lowest PE of $30.32 \%$ ) should be the first option to estimate ETo in the Abha Region followed by Turc then Albrecht. The worst performance was given by Makkink modified method.

Table 6. Evaluation of criteria parameters for validating ET estimate between 2001-2017

\begin{tabular}{c|c|c|c|c|c}
\hline Method & R2 & SEE & RMSE & MBE & PE \\
\hline Trabert-ET0(mm) & 0.92 & 0.03 & 2.47 & -2.35 & 89.43 \\
Mahringer-ET0(mm) & 0.92 & 0.07 & 2.13 & -2.03 & 77.27 \\
Penman-ET0(mm) & 0.92 & 0.11 & 1.78 & -1.70 & 64.71 \\
Albrecht-ET0(mm) & 0.94 & 0.11 & 1.66 & -1.59 & 60.58 \\
Priestly Taylor-ET0(mm) & 0.70 & 0.59 & 1.30 & 1.16 & 44.25 \\
Turc -ET0(mm) & 0.67 & 0.16 & 1.15 & -0.93 & 35.53 \\
Makkink-Modified Hansen ET0(mm) & 0.48 & 0.49 & 1.76 & 1.65 & 62.73 \\
Makkink 1957 ET0(mm) & 0.48 & 0.43 & 1.21 & 1.03 & 39.21 \\
Valiantaz ET0 (mm) & 0.65 & 0.26 & 0.99 & -0.80 & 30.32 \\
\hline
\end{tabular}

\section{Ranking of ETo Estimation}

The primary requirement of ranking is to get weightage for statistical indices which is computed by Entropy method (Table 7). The values depicted as shown in Table 8 below describes the ranking of ETo Estimate of nine models for the period between 1978-2017. It was observed that the Mahringer model ranked number 1 while Makkink Modified model was in the last position for the case of without calibrating the ETo equation. Also, the ranking of ETo Estimate of nine models after calibrating for the period between 1978-2000 are shown in Table 9, Albrecht model ranked number 1 and Valiantaz model was in the last position. Moreover, the ranking as shown in Table 10 gives the ETo Estimate of nine models for Validating the Calibrated equation for the period between 2001-2017. Mahringer model ranked number 1 and Priestly Taylor was in the last position. Hence, it is quite clear that Mahringer method is the most promising model which can be used as an alternative to FAO56-PM model. The comparative study of Ranking is shown in Fig. 7. From the whole ranking analysis, it can be observed that the ranks' results did not exactly match with each other and in some cases considerably differs from the other.

Table 7. Weightage by Entropy Method

\begin{tabular}{c|c|c|c|c|c|c}
\hline Criteria & $\mathbf{R}^{\mathbf{2}}$ & SEE & RMSE & MBE & PE & Sum \\
\hline Weightage Evaluation & 0.05 & 0.67 & 0.08 & 0.11 & 0.10 & 1.00 \\
Weightage Calibration & 0.01 & 0.13 & 0.13 & 0.44 & 0.29 & 1.00 \\
Weightage Validation & 0.06 & 0.62 & 0.08 & 0.12 & 0.12 & 1.00 \\
\hline
\end{tabular}


Table 8. Ranking of ETo estimate of nine models for period between 1978-2017

\begin{tabular}{c|c|c|c|c|c|c}
\hline Sn & Method & Si+ & Si- & Si++si- & Ci & Rank \\
\hline $\mathbf{1}$ & Trabert-ET0(mm) & 0.048558 & 0.393007 & 0.441566 & 0.890032 & 2 \\
$\mathbf{2}$ & Mahringer-ET0(mm) & 0.036844 & 0.373905 & 0.41075 & 0.9103 & 1 \\
$\mathbf{3}$ & Penman-ET0(mm) & 0.060846 & 0.349965 & 0.410811 & 0.851888 & 5 \\
$\mathbf{4}$ & Albrecht-ET0(mm) & 0.054297 & 0.355604 & 0.4099 & 0.867537 & 3 \\
$\mathbf{5}$ & Priestly Taylor-ET0(mm) & 0.394267 & 0.037161 & 0.431427 & 0.086134 & 4 \\
$\mathbf{6}$ & Turc -ET0(mm) & 0.109701 & 0.287544 & 0.397245 & 0.723845 & 6 \\
$\mathbf{7}$ & Makkink-Modified Hansen ET0(mm) & 0.338601 & 0.0735 & 0.412101 & 0.178354 & 9 \\
$\mathbf{8}$ & Makkink 1957 ET0(mm) & 0.292096 & 0.10872 & 0.400815 & 0.271246 & 8 \\
$\mathbf{9}$ & Valiantaz ET0 (mm) & 0.176656 & 0.220993 & 0.397648 & 0.555749 & 7 \\
\hline
\end{tabular}

Table 9. Ranking of ETo estimate of nine models after calibrating for period between $1978-2000$

\begin{tabular}{c|c|c|c|c|c|c}
\hline Sn & Method & Si+ & Si- & Si++si- & Ci & Rank \\
\hline $\mathbf{1}$ & Trabert-ET0(mm) & 0.008826 & 0.355287 & 0.364113 & 0.97576 & 2 \\
$\mathbf{2}$ & Mahringer-ET0(mm) & 0.140201 & 0.300896 & 0.441096 & 0.682154 & 5 \\
$\mathbf{3}$ & Penman-ET0(mm) & 0.024904 & 0.30044 & 0.325345 & 0.923453 & 3 \\
$\mathbf{4}$ & Albrecht-ET0(mm) & 0.000438 & 0.321685 & 0.322123 & 0.998639 & 1 \\
$\mathbf{5}$ & Priestly Taylor-ET0(mm) & 0.150164 & 0.223602 & 0.373766 & 0.598241 & 6 \\
$\mathbf{6}$ & Turc -ET0(mm) & 0.125925 & 0.329778 & 0.455703 & 0.723669 & 4 \\
$\mathbf{7}$ & Makkink-Modified Hansen ET0(mm) & 0.265806 & 0.192504 & 0.45831 & 0.42003 & 8 \\
$\mathbf{8}$ & Makkink 1957 ET0(mm) & 0.267363 & 0.194648 & 0.462011 & 0.421306 & 7 \\
$\mathbf{9}$ & Valiantaz ET0 (mm) & 0.334992 & 0.107558 & 0.44255 & 0.243042 & 9 \\
\hline
\end{tabular}

Table 10. Ranking of ETo estimate of nine models for validating the calibrated equation for period between 2001-2017

\begin{tabular}{c|c|c|c|c|c|c}
\hline Sn & Method & Si+ & Si- & Si++si- & Ci & Rank \\
\hline $\mathbf{1}$ & Trabert-ET0(mm) & 0.060765 & 0.366145 & 0.42691 & 0.857663 & 2 \\
$\mathbf{2}$ & Mahringer-ET0(mm) & 0.045617 & 0.344014 & 0.389631 & 0.882922 & 1 \\
$\mathbf{3}$ & Penman-ET0(mm) & 0.07262 & 0.317463 & 0.390083 & 0.813835 & 4 \\
$\mathbf{4}$ & Albrecht-ET0(mm) & 0.069836 & 0.31736 & 0.387196 & 0.819637 & 3 \\
$\mathbf{5}$ & Priestly Taylor-ET0(mm) & 0.367337 & 0.046783 & 0.414119 & 0.112969 & 9 \\
$\mathbf{6}$ & Turc -ET0(mm) & 0.088572 & 0.28517 & 0.373742 & 0.763012 & 5 \\
$\mathbf{7}$ & Makkink-Modified Hansen ET0(mm) & 0.304764 & 0.08038 & 0.385144 & 0.208702 & 8 \\
$\mathbf{8}$ & Makkink 1957 ET0(mm) & 0.263072 & 0.114761 & 0.377833 & 0.303735 & 7 \\
$\mathbf{9}$ & Valiantaz ET0 (mm) & 0.151847 & 0.221546 & 0.373392 & 0.593332 & 6 \\
\hline
\end{tabular}

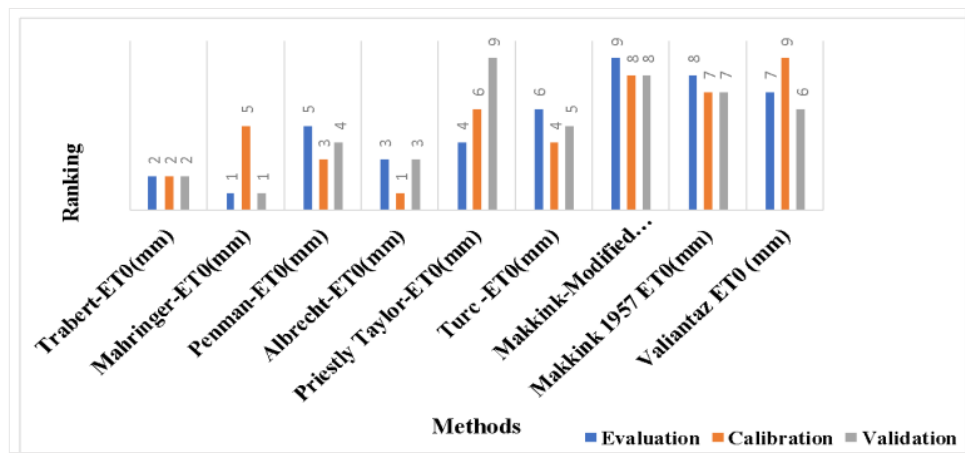

Figure 7. Comparison of ranking of ETo estimates based on ETo equation, Calibrated equation and Validating the calibrated equation 


\section{Discussions}

Different ETo models were used around the world to compute the reference evapotranspiration by using the climatic parameters such as mean temperature, relative humidity, solar radiation and wind speed. FAO56-PM model recommended by the Food and Agricultural Organization (FAO) has been recognized as the most accurate model for estimating the ETo over the past few decades. But due to the constraint of limited climatic parameters, FAO56-PM is not suitable to be implemented. Thus, to find an alternative technique of accurate prediction of ETo, the performance of the nine empirical models were evaluated against the FAO56-PM model by using the four common statistical approaches: root-mean-square error (RMSE), mean bias error (MBE), standard error of estimates (SEE) and percent error (PE). Additionally, a linear regression model was adopted to calibrate and validate the performance of the empirical models during the 1978-2000 and 2001-2017 time periods, respectively. The current study compared four mass transfer methods (Trabert, Mahringer, Penman and Albrecht), four radiation-based methods (Priestly Taylor, Turc, Makkink and Makkink Modified) and one combination-based method against the FAO56-PM method.

The result evaluated from 1978-2017 showed that the mass transfer method performed better without calibration with the highest the coefficient of determination was the Albrecht $\left(\mathrm{R}^{2}=0.96\right)$ followed by the combined method and lastly was the radiation method. The statistical output showed that the combined model (Valiantzas equation) performed better as compared to the other model with an RMSE value of 0.98 $\mathrm{mm} /$ day, $\mathrm{MBE}=0.83, \mathrm{PE} \%=33.53$ and $\mathrm{SEE}=0.268 \mathrm{~mm} /$ day. The higher precision of the combined models might be due to the combination of the most suitable and important meteorological parameters being incorporated. Similar results were also obtained previously after evaluating six ETo equations (Trabert, Mahringer, Penman (1948), Albrecht, Valiantzas1 and Valiantzas2) for the Senegal River Delta (Djaman et al., 2016a). The result is in agreement with the present work with $\mathrm{R}^{2}>0.60$ for the daily ETo estimates. The Valiantzas2 equation was the best model for the Senegal River Delta and had the lowest root mean squared difference (RMSE) of $0.45 \mathrm{~mm} /$ day and the lowest percent error of estimate (PE) about 7.1\%. The findings of the research are in agreement with the study conducted by other researchers (Djaman et al., 2015) after evaluating the sixteen reference evapotranspiration methods under sahelian conditions in the Senegal River Valley. However, Valiantzas equation was found to be the promising equations that could be used for the reference evapotranspiration estimation in the Senegal River Valley. After calibrating the empirical equation from (1978-2000), it was observed that there was a remarkable improvement in the performance of these nine equations. Additionally, the findings revealed that the calibration improved the reliability and consistency of different ETo equations. The correlation value significantly increased. Moreover, the statistical measures such as RMSE, SEE, MBE and PE significantly reduced for all the models but both the Albrect and Makkink models gave the least correlation. However, no improvement was seen in Turc model with its SEE. But, there was a remarkable improvement in the performance of equations. Additionally, the findings revealed that calibration improved the reliability and consistency of different Valiantzas equations. Valipour (2015) reported that there was an improvement in the calibrated Trabert and Mahringer equations in Iran with MBE as low as $0.02 \mathrm{~mm} /$ day. He indicated that the Trabert model can skip the calibration process to generate the best performance in Iran. Meanwhile, Valiantzas equations were suitable for ETo estimation as compared to PM-ETo in the Pilbara 
region of Western Australia. But, their performance can be further improved through calibration (Ahooghalandari et al., 2017).

The calibrated Valiantzas equation showed the best performance using the limited data in Guizhou Province, China (Gao et al., 2015). This phenomenon was similar to the performance's results of the calibrated Valiantzas equation at Adana Station in Turkey (Kisi and Zounemat-Kermani, 2014). The calibrated Trabert, Albrecht and the Mahringer equations showed different performance relative to the PM-ETo, depending on the region. But, the better performance was observed at Ndiaye $35 \mathrm{~km}$ inland than Saint-Louis at the coast. The dependency of mass transfer equation on the vapor pressure was too small. It was reported that better performance of the Trabert and Mahringer equations were in inland area than at the coastal area in the Senegal River Valley (Djaman et al., 2015). The climate variables in a coastal area like Saint-Louis located near the mouth of the Senegal river might be influenced by surrounding water (Hargreaves, 1994). These results were contradicted with the findings of Valipour (2015) who reported that the calibrated mass transfer ETo equation had better performance near the Caspian Sea and the Persian Gulf in Iran with RH higher than $65 \%$ than the other area. The validation of the nine ETo equations for the 2001-2017 shows a strong correlation between the calibrated equations to the PM estimates. Similar RMSE, MBE and PE were obtained from the calibration and validation with only slightly decrease in $\mathrm{R}^{2}$. The magnitude of RMSE, MBE and PE were acceptable for ETo estimation for any nine ETo equation at Abha.

From the ranking of evaluated model and during validation of calibrating ETo model, it was observed that Mahringer ranked number 1 and Makkink modified gives worst performance during evaluation and Priestly Taylor was in the last position during the validation of the calibrated equation. Hence, Mahringer method is the most promising model which can be used as an alternative to the FAO Penman-Monteith method. Moreover, during calibration the Albrecht model is found to be best one and Valiantaz shows the worst result. The overall improvement result after calibration and during validation against the evaluated evapotranspiration for the first three rank model is as shown in Fig. 8. It clearly shows that the evaluation criteria significantly improved with respect to the evaluated equation after calibration and validation. However, there is no considerable improvement in the coefficient of determination in some cases. The outcomes of the study will provide meaningful guidance for agricultural production, hydrological planning and management in the vital region as well as other regions with similar climates.

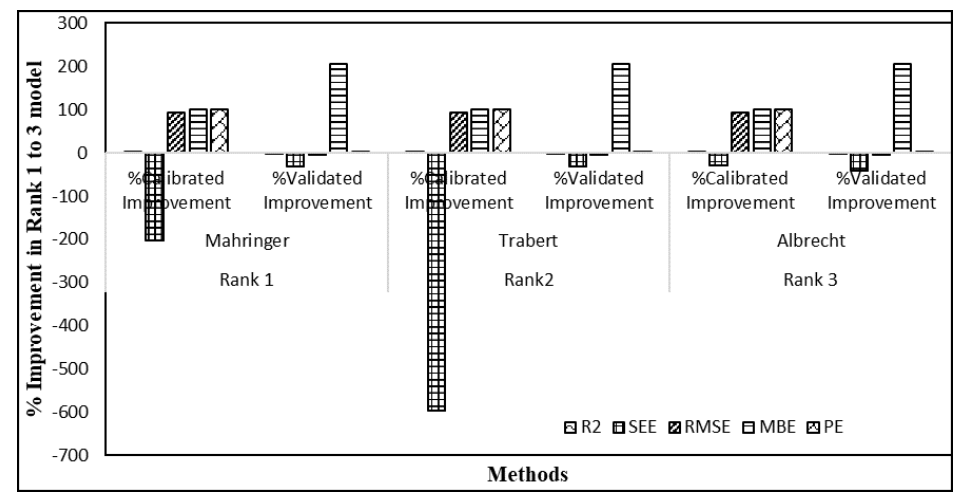

Figure 8. Comparative study of rank 1 to 3 evaluation criteria 


\section{Conclusions}

The current study was performed with an aim to evaluate the nine reference evapotranspiration models with respect to standard FAO56-PM model in the semi-arid region of Kingdom of Saudi Arabia. The nine evapotranspiration models have been successfully evaluated (period: 1978-2017), calibrated (period: 1978-2000) and further validated (period: 2001-2017). Based on the statistical indices as criteria, the ranking was performed using multi criteria decision making (weightage by Entropy and performance score by TOPSIS) in order to observe the performance against the FAO56PM equation under the available climatic conditions in Abha city. Based on the analysis result following inference can be made

- There was a remarkable improvement in the performance of calibrated equation. Moreover, the calibration approach improves the reliability and consistency of different evapotranspiration equation.

- The ranking of evaluated evapotranspiration models (1978-2017) and during validation (2001-2017) shows that the Mahringer model performed very well. While during calibration (1978-2000), Albrecht model shows better performance. Hence Mahringer model was the most promising model and can be used as an alternative approach to Standard FAO56-PM model.

- In the case of data limitations, the equations calibrated in this study are recommended for ETo estimation in the Abha region.

- The Use of multiple criterion decision-making methods (MCDM) allows a researcher to choose the best alternative out of a number of the considered alternatives.

- The findings, are likely to help in diminishing the error associated with ETo estimation, and the recognized models in this study could be utilized as part of further examinations in the related field.

- To some extent, it is expected that the conclusions of this study can be used in regions with similar topography and climatic conditions in the world.

- The results of this study could be used by the water management system, crop cultivators, crop advisors, researchers and students from universities and research centres. Moreover, it is beneficial for the decision maker in the vast field of agriculture, hydrology and environment.

- Further research is required in order to assess the effect of using reduced set of data for daily hourly ETo estmation. Moreover, the seasonal changes in ETo is also need to be investigated in future.

Acknowledgments. The authors extend their appreciation to the Deanship of Scientific Research at King Khalid University for funding this work through research group program under grant number (R.G.P.1/85/40). The authors of current work wish to thank Universiti Tecknologi Malaysia, Johor Bahru for their facilities and Lab support. The outcome of this research paper is based on the excerpts of current ongoing Ph.D research study. We would also like to thank general authority of the meteorological department, Abha, Asir region, Saudi Arabia for providing the weather data.

Conflict of interests. The authors declare no conflict of interests. 


\section{REFERENCES}

[1] Abo-Ghobar, H. M., Mohammad, S. (1995): Evapotranspiration measurement by lysimeters in a desert climate. - Arab Gulf Journal of Scientific Research 13(1): 109-122.

[2] Ahooghalandari, M., Khiadani, M., Jahromi, M. E. (2017): Calibration of Valiantzas' reference evapotranspiration equations for the Pilbara region, Western Australia. Theoretical and applied climatology 128(3-4): 845-856.

[3] Alamanos, A., Mylopoulos, N., Loukas, A., Gaitanaros, D. (2018): An integrated multicriteria analysis tool for evaluating water resource management strategies. - Water 10(12): 1795.

[4] Alblewi, B., Gharabaghi, B., Alazba, A. A., Mahboubi, A. A. (2015): Evapotranspiration models assessment under hyper-arid environment. - Arabian Journal of Geosciences 8(11): 9905-9912.

[5] Albrecht, F. (1950): Die methoden zur bestimmung der verdunstung der natürlichen erdoberfläche. - Archiv für Meteorologie, Geophysik und Bioklimatologie, Serie B 2(12): $1-38$.

[6] Allen, R. G. (1996): Assessing integrity of weather data for reference evapotranspiration estimation. - Journal of irrigation and drainage engineering 122(2): 97-106.

[7] Allen, R. G., Pereira, L. S., Raes, D., Smith, M. (1998): Crop EvapotranspirationGuidelines for computing crop water requirements. - FAO Irrigation and drainage paper 56. FAO, Rome 300(9): D05109.

[8] Al-Omran, A. M., Al-Ghobari, H. M., Alazba, A. A. (2004): Determination of evapotranspiration of tomato and squash. - International Agricultural Engineering Journal 13(142): 27-36.

[9] Bogawski, P., Bednorz, E. (2014): Comparison and validation of selected evapotranspiration models for conditions in Poland (Central Europe). - Water Resources Management 28(14): 5021-5038.

[10] Ėadro, S., Uzunoviæ, M., Žurovec, J., Žurovec, O. (2017): Validation and calibration of various reference evapotranspiration alternative methods under the climate conditions of Bosnia and Herzegovina. - International Soil and Water Conservation Research 5(4): 309-324.

[11] Djaman, K., Balde, A. B., Sow, A., Muller, B., Irmak, S., N'Diaye, M. K., Manneh, B., Moukoumbi, Y. D., Futakuchi, K., Saito, K. (2015): Evaluation of sixteen reference evapotranspiration methods under sahelian conditions in the Senegal River Valley. Journal of Hydrology: Regional studies 3: 139-159.

[12] Djaman, K., Tabari, H., Balde, A. B., Diop, L., Futakuchi, K., Irmak, S. (2016a): Analyses, calibration and validation of evapotranspiration models to predict grassreference evapotranspiration in the Senegal river delta. - Journal of Hydrology: Regional Studies 8: 82-94.

[13] Djaman, K., Irmak, S., Kabenge, I., Futakuchi, K. (2016b): Evaluation of FAO-56 penman-monteith model with limited data and the valiantzas models for estimating grassreference evapotranspiration in Sahelian conditions. - Journal of Irrigation and Drainage Engineering 142(11): 04016044.

[14] Djaman, K., Koudahe, K., Allen, S., O’Neill, M., Irmak, S. (2017a): Validation of Valiantzas' reference evapotranspiration equation under different climatic conditions. Irrigation \& Drainage Systems Engineering 6(3): 196.

[15] Djaman, K., Koudahe, K., Akinbile, C. O., Irmak, S. (2017b): Evaluation of eleven reference evapotranspiration models in semiarid conditions. - Journal of Water Resource and Protection 9(12): 1469.

[16] ElNesr, M., Alazba, A., Abu-Zreig, M. (2010): Spatio-temporal variability of evapotranspiration over the Kingdom of Saudi Arabia. - Applied engineering in agriculture 26(5): 833-842. 
[17] Gabiri, G., Leemhuis, C., Diekkrüger, B., Näschen, K., Steinbach, S., Thonfeld, F. (2019): Modelling the impact of land use management on water resources in a tropical inland valley catchment of central Uganda, East Africa. - Science of the Total Environment 653: 1052-1066.

[18] Gao, X., Peng, S., Xu, J., Yang, S., Wang, W. (2015): Proper methods and its calibration for estimating reference evapotranspiration using limited climatic data in Southwestern China. - Archives of Agronomy and Soil Science 61(3): 415-426.

[19] Gupta, A. P., Harboe, R., Tabucanon, M. T. (2000): Fuzzy multiple-criteria decision making for crop area planning in Narmada river basin. - Agricultural Systems 63(1): 118.

[20] Hansen, S. (1984): Estimation of potential and actual evapotranspiration. - Nordic Hydrol. 15: 205-212.

[21] Hargreaves, G. H. (1994): Simplified coefficients for estimating monthly solar radiation in North America and Europe. - Utah State Univ, Logan, Utah.

[22] Häusler, M., Conceição, N., Tezza, L., Sánchez, J. M., Campagnolo, M. L., Häusler, A. J., Ferreira, M. I. (2018): Estimation and partitioning of actual daily evapotranspiration at an intensive olive grove using the STSEB model based on remote sensing. - Agricultural water management 201: 188-198.

[23] Hu, Z., Yu, G., Zhou, Y., Sun, X., Li, Y., Shi, P., Li, S. (2009): Partitioning of evapotranspiration and its controls in four grassland ecosystems: Application of a twosource model. - Agricultural and Forest Meteorology 149(9): 1410-1420.

[24] Islam, S., Abdullah, R. A. B., Algahtani, A., Irshad, K., Hirol, H. (2019a): Performance of vapour pressure models in the computation of vapour pressure and evapotranspiration in Abha, Asir region, Saudi Arabia. - Applied Ecology and Environmental Research 17(4): 9691-9715.

[25] Islam, S., Abdullah, R. A. B., Algahtani, A., Irshad, K., Hirol, H. (2019b): Performance evaluation off mass transfer-based method using global performance index in semi-arid region, Saudi Arabia. - Applied Ecology and Environmental Research 17(5): 1112111141.

[26] Janssen, R., Goosen, H., Verhoeven, M. L., Verhoeven, J. T., Omtzigt, A. Q. A., Maltby, E. (2005): Decision support for integrated wetland management. - Environmental Modelling \& Software 20(2): 215-229.

[27] Jiang, S., Wang, J., Zhao, Y., Shang, Y., Gao, X., Li, H., Wang, Q., Zhu, Y. (2017): Sustainability of water resources for agriculture considering grain production, trade and consumption in China from 2004 to 2013. - Journal of Cleaner Production 149: 12101218.

[28] Jin, N., Ren, W., Tao, B., He, L., Ren, Q., Li, S., Yu, Q. (2018): Effects of water stress on water use efficiency of irrigated and rainfed wheat in the Loess Plateau, China. - Science of the total environment 642: 1-11.

[29] Kisi, O., Zounemat-Kermani, M. (2014): Comparison of two different adaptive neurofuzzy inference systems in modelling daily reference evapotranspiration. - Water resources management 28(9): 2655-2675.

[30] Lang, D., Zheng, J., Shi, J., Liao, F., Ma, X., Wang, W., Chen, X., Zhang, M. (2017): A comparative study of potential evapotranspiration estimation by eight methods with FAO Penman-Monteith method in southwestern China. - Water 9(10): 734.

[31] Mahringer, W. (1970): Verdunstungsstudien am neusiedler See. - Archiv für Meteorologie, Geophysik und Bioklimatologie, Serie B 18(1): 1-20.

[32] Makkink, G. F. (1957): Testing the Penman formula by means of lysimeters. - Journal of the Institution of Water Engineers 11: 277-288.

[33] Makropoulos, C. K., Natsis, K., Liu, S., Mittas, K., Butler, D. (2008): Decision support for sustainable option selection in integrated urban water management. - Environmental modelling and software 23(12): 1448-1460. 
[34] Mustafa, M. A., Akabawi, K. A., Zoghet, M. F. (1989): Estimation of reference crop evapotranspiration for the life zones of Saudi Arabia. - Journal of arid environments 17(3): 293-300.

[35] Pandey, P. K., Dabral, P. P., Pandey, V. (2016): Evaluation of reference evapotranspiration methods for the northeastern region of India. - International Soil and Water Conservation Research 4(1): 52-63.

[36] Pandey, V., Pandey, P. K. (2018): Calibration and ranking of Valiantzas reference evapotranspiration equations under the humid climate of northeast India. - Journal of Water and Climate Change: jwc2018305.

[37] Penman, H. L. (1948): Natural evaporation from open water, bare soil and grass. Proceedings of the Royal Society of London. Series A. Mathematical and Physical Sciences 193(1032): 120-145.

[38] Pietersen, K. (2006): Multiple criteria decision analysis (MCDA): A tool to support sustainable management of groundwater resources in South Africa. - Water SA 32(2): 119-128.

[39] Priestley, C. H. B., Taylor, R. J. (1972): On the assessment of surface heat flux and evaporation using large-scale parameters. - Monthly weather review 100(2): 81-92.

[40] Qin, X. S., Huang, G. H., Chakma, A., Nie, X. H., Lin, Q. G. (2008): A MCDM-based expert system for climate-change impact assessment and adaptation planning-A case study for the Georgia Basin, Canada. - Expert Systems with Applications 34(3): 21642179.

[41] Saeed, M. (1986): The estimation of evapotranspiration by some equations under hot and arid conditions. - Transactions of the ASAE 29(2): 434-0438.

[42] Salih, A. M., Sendil, U. (1984): Evapotranspiration under extremely arid climates. Journal of irrigation and drainage engineering 110(3): 289-303.

[43] Senent-Aparicio, J., Pérez-Sánchez, J., Carrillo-García, J., Soto, J. (2017): Using SWAT and Fuzzy TOPSIS to assess the impact of climate change in the headwaters of the Segura River Basin (SE Spain). - Water 9(2): 149.

[44] Srdjevic, B., Medeiros, Y. D. P., Faria, A. S. (2004): An objective multi-criteria evaluation of water management scenarios. - Water resources management 18(1): 35-54.

[45] Tie, Q., Hu, H., Tian, F., Holbrook, N. M. (2018): Comparing different methods for determining forest evapotranspiration and its components at multiple temporal scales. Science of the Total Environment 633: 12-29.

[46] Trabert, W. (1896): Neue beobachtungen über verdampfungsgeschwindigkeiten. Meteorol Z 13: 261-263.

[47] Trajkovic, S., Kolakovic, S. (2009): Evaluation of reference evapotranspiration equations under humid conditions. - Water Resource Management 23: 3057.

[48] Turc, L. (1961): Water requirements assessment of irrigation, potential evapotranspiration: simplified and updated climatic formula. - Annales Agronomiques 12: 13-49.

[49] Valiantzas, J. D. (2013): Simplified forms for the standardized FAO-56 PenmanMonteith reference evapotranspiration using limited weather data. - Journal of Hydrology 505: 13-23.

[50] Valipour, M. (2015): Investigation of Valiantzas' evapotranspiration equation in Iran. Theoretical and applied climatology 121(1-2): 267-278.

[51] Vinogradova, I., Podvezko, V., Zavadskas, E. (2018): The recalculation of the weights of criteria in MCDM methods using the bayes approach. - Symmetry 10(6): 205.

[52] Wei, Y., Tang, D., Ding, Y., Agoramoorthy, G. (2016): Incorporating water consumption into crop water footprint: A case study of China's South-North Water Diversion Project. - Science of The Total Environment 545: 601-608.

[53] Xu, J., Peng, S., Ding, J., Wei, Q., Yu, Y. (2013): Evaluation and calibration of simple methods for daily reference evapotranspiration estimation in humid East China. Archives of Agronomy and Soil Science 59(6): 845-858. 
[54] Zarghami, M., Abrishamchi, A., Ardakanian, R. (2008): Multi-criteria decision making for integrated urban water management. - Water Resources Management 22(8): 10171029.

[55] Zhai, L., Feng, Q., Li, Q., Xu, C. (2010): Comparison and modification of equations for calculating evapotranspiration (ET) with data from Gansu Province, Northwest China. Irrigation and drainage 59(4): 477-490. 